\title{
Characterization of generative development in early maturing litchi 'Early Big', a novel cultivar in Taiwan
}

\author{
JenYu Chang ${ }^{1}$, Yu-An Chang ${ }^{1}$, Lisa Tang ${ }^{2}$ and Jer-Way Chang ${ }^{1, \star}$ \\ 1 Chiayi Agricultural Experiment Branch, Taiwan Agricultural Research Institute, Chiayi, Taiwan, Republic of China \\ 2 Department of Botany and Plant Science, University of California, Riverside, CA 92507, USA
}

Received 12 September 2014 - Accepted 28 May 2015

\begin{abstract}
Introduction. A short harvest window is common in litchi production worldwide, leading to imbalance between supply and demand for fresh fruit. This problem can be mitigated with early-maturing cultivars, such as 'Early Big', released in 2010 in Taiwan. Our goal was to characterize the generative development in this novel litchi cultivar. Materials and methods. The patterns of female flowering and fruit development, and fruit abscission were investigated in 'Early Big' litchi in 2013 and 2014. The relationship between the second round $\left(2^{\text {nd }} \mathrm{R}\right)$ blooming and the first round $\left(1^{\text {st }} \mathrm{R}\right)$ fruit was studied. The ambient temperature in both years was recorded. Results and discussion. 2-3 weeks after full female bloom (AFFB) the $2^{\text {nd }} \mathrm{R}$ flowering occurred, followed by fruit abscission with loss of $95 \%$ fruit within 4 weeks AFFB in 'Early Big' litchi, resulting in low yield at harvest. The $2^{\text {nd }} \mathrm{R}$ blooming was negatively correlated with the $1^{\text {st }} \mathrm{R}$ fruit retention rate from week 4 AFFB in 2013. Overall, the period of low temperature from November through to the following March was longer in 2013/2014 than in 2012/2013. The trait of early maturing in 'Early Big' is mainly due to early flowering. Temperature may be related to the generative development in 'Early Big'. The accumulation of low temperature in early spring may be related to poor initial fruit set. Conclusion. The presence of $2^{\text {nd }} \mathrm{R}$ flowering also potentially reduced the $1^{\text {st }} \mathrm{R}$ fruit set and retention. These issues must be addressed to develop field strategies to improve yield in 'Early Big' litchi.
\end{abstract}

Keywords: Taiwan / Litchi chinensis / earliness / fruit set / genetic improvement

Résumé - Caractérisation du développement floral du litchi précoce 'Early Big', un nouveau cultivar à Taïwan. Introduction. Une courte période de récolte est le lot commun à la production de litchi dans le monde entier, conduisant à un déséquilibre entre l'offre et la demande en fruits frais. Un tel problème pourrait être atténué avec des variétés précoces, telle 'Early Big' introduite en 2010 à Taiwan. L'objectif de notre étude consiste à caractériser le développement floral de ce nouveau cultivar de litchi. Matériel et méthodes. Les caractéristiques de floraison femelle et du développement et de l'abscission des fruits du cultivar de litchi 'Early Big' ont été étudiées sur 2013 et 2014 . La relation entre la floraison en second cycle $\left(2^{\text {nd }} R\right)$ et la production fruitière du premier cycle $\left(1^{\text {st }} \mathrm{R}\right)$ a été particulièrement étudiée. La température ambiante au cours de ces deux années a été enregistrée. Résultats et discussion. Deux-trois semaines après la pleine floraison femelle (AFFB), une floraison de second cycle $2^{\text {nd }} \mathrm{R}$ est survenue, suivie par l'abscission de fruits causant une perte en fruits de $95 \%$ dans les 4 semaines suivant l'AFFB, et un faible rendement à la récolte des arbres 'Early Big'. Nous avons corrélé négativement la floraison $2^{\text {nd }} \mathrm{R}$ avec le taux de rétention en fruits $1^{\text {st }} \mathrm{R}$ depuis la $4^{\mathrm{e}}$ semaine AFFB en 2013. Dans l'ensemble, la période de basses températures de Novembre à Mars suivant était plus longue en 2013/2014 qu'en 2012/2013. Le critère de précocité chez 'Early Big' est principalement dû à une floraison précoce. La température est sans doute responsable des perturbations du développement floral d'Early Big'. L'accumulation de basses températures au début du printemps peut être liée à la nouaison initiale. Conclusion. La présence d'un second cycle de floraison $2^{\text {nd }} \mathrm{R}$ réduit potentiellement la nouaison et la charge en fruits du premier cycle $1^{\text {st }} \mathrm{R}$. Ces problèmes doivent être étudiés pour élaborer des stratégies sur le terrain en vue d'améliorer les rendements du litchi 'Early Big'.

Mots clés : Taïwan / Litchi chinensis / précocité / mise à fruit / amélioration génétique

\footnotetext{
^ Corresponding author: jerway@dns.caes.gov.tw
} 


\section{Introduction}

Litchi (Litchi chinensis, Sapindaceae) is one of the most popular subtropical fruits in the world, especially in its native regions, Eastern and Southern Asia. In Taiwan, the history of litchi cultivation can be traced back more than 300 years. There were about 12,000 ha litchi orchards until the 1980s. 'Hak Ip' became the most cultivated litchi cultivar in Taiwan because of its high yield, ideal fruit quality and low production cost. Currently, more than $70 \%$ of the litchi-growing area in Taiwan has been cultivated with 'Hak Ip' [1]. This dominance of a single cultivar has confined the litchi harvest to June, leading to imbalance between the supply and demand of fresh fruit. Flowering and fruit development of litchi are strongly influenced by environmental factors, internal conditions of trees, pests and pathogens [2-5]. In general, an adequately cool temperature and flush maturity are essential for litchi flowering [6-8]. Subsequently, successful pollination and fertilization require functional ovules, pollen donors and pollinators under ideal environmental conditions [9-11]. Sufficient assimilate supplies and management of pests and diseases are critical for the following fruit set and development [12-14]. Since most litchi fruit are highly perishable, the shelf life of fresh litchi fruit is generally less than 30 days under 2 to $5{ }^{\circ} \mathrm{C}$ storage temperature [15]. The extended production season was therefore expected to mitigate the marketing issues.

The harvest time of litchi fruit can be adjusted among regions by their latitudinal and/or altitudinal differences, and the shelf life can be extended by postharvest approaches or processing. It is difficult, however, to achieve the earlymaturing trait in most fruit crops, including litchi, by cultural practices. On the other hand, genetic improvement was a promising method to obtain divergent lines [16]. In Taiwan, the Taiwan Agricultural Research Institute started the litchi breeding program in 1982 [17], and 7 novel litchi cultivars, named the 'Tainung series', have been released up to now [1]. The 'Tainung No.7' or 'Early Big' cultivar selected from 'Sah Keng' open-pollinated offspring is known for its earlymaturing trait and large fruit size compared with other commercial cultivars [18]. The harvest season of 'Early Big' is about 10 days earlier than the early-season cultivar 'Yu Her Pau' (named 'Feizixiao' or 'Fay Zee Siu' in other countries) and 17 to 21 days earlier than 'Hak Ip' grown in the same region; in addition, the average fruit weight is generally more than $30 \mathrm{~g}$ [18]. 'Early Big' has a better fruit appearance (with large size and red color) and quality compared with other minor but marketable early-maturing cultivars, such as 'Nansi Early' or 'Sanyuehong'. Therefore, 'Early Big' litchi has become a popular cultivar for orchard renewal among growers since its release in 2010. The phenology of 'Early Big' is about half a month earlier than its parent 'Sah Keng' during the generative stages [18]. However, its reproductive development, including flowering, fruit set and fruit growth, has remained unclear until now. This study focused on the generative growth of 'Early Big', since the patterns of flowering and fruit bearing in this early-maturing variety can be used as indicators for growers to develop strategies for field management.

\section{Materials and methods}

\subsection{Fruit growth and quality traits}

Seventeen-year-old 'Early Big' litchi trees grown in Chiayi Agricultural Experiment Branch (Lat. 23⒉ $9^{\prime} \mathrm{N}$, Long. $120^{\circ} 28^{\prime} \mathrm{E}$, Alt. $70 \mathrm{~m}$ asl) were used to study the growth pattern of fruit in 2013. Fruits with normal seed produced by the first round $\left(1^{\text {st }} \mathrm{R}\right)$ female flowers were collected weekly after bloom from labeled panicles that did not generate the second round $\left(2^{\text {nd }} \mathrm{R}\right)$ female flowers later on. Fresh and dry (incubated at $65{ }^{\circ} \mathrm{C}$ in an oven for 7 days) masses of the pericarp, aril and seed of 21 fruits were measured individually. The edible ratio in this study was defined as the percentage of aril fresh weight within a single fruit. Total soluble solids (TSS) content was determined in the juice of 12 fruits collected weekly from week 7 after full female bloom (AFFB), with one fruit representing one replicate, using a hand-held refractometer (Atago, Japan). Titratable acidity (TA, titrated to $\mathrm{pH} 8.3$ ), represented by the content of malic acid, the most abundant organic acid component in litchi arils [19], was quantified with the 848 Titrino Plus (Metrohm, USA). Juice samples extracted from the pulp of 3 fruits represented one replicate and 4 replications were used for TA measurement, and assessed weekly from week 6 AFFB.

\subsection{Female blooming and fruit abscission patterns}

The patterns of female blooming and fruit abscission were studied using four 6-year-old 'Early Big' litchi trees (height: ca. $3.5 \mathrm{~m}$, diameter: ca. $4.5 \mathrm{~m}$; grown on loams and set up in $5.7 \times 5.7 \mathrm{~m}$ square planting) in 2013 and six 7-year-old trees in 2014 in the same orchard as above. The drip irrigation system was applied during the fruit development season after the end of April. The number of female flowers [10] on 12 panicles in each tree was recorded 3 times a week. The number of retained fruit per tree was quantified weekly from full female bloom through to harvest for 11 weeks. The yield of each tree was also recorded respectively. The relative fruit abscission rate ( $\mathrm{rFAR}$ ) in $1^{\text {st }} \mathrm{R}$ bearing between two subsequent weeks was calculated using the following formula:

$$
\operatorname{rFAR}=\left(1-\frac{N_{i+1}}{N_{i}}\right) \times 100 \%
$$

where $N$ is the number of fruit retained on the labeled panicles in each tree, and $i(i=1$ to 10) is the number of weeks AFFB.

The fruit retention rate (FRR) in the $1^{\text {st }} \mathrm{R}$ bearing each week was calculated using the following formula:

$$
\mathrm{FRR}=\frac{N_{k}}{N_{1}} \times 100 \%
$$

where $N$ is the number of fruit retained on the labeled panicles in each tree, and $k$ ( $k=2$ to 11$)$ is the number of weeks AFFB.

The number of the female flowers per panicle, the ratio of panicles producing female flowers, and the rFAR and FRR (adjusted by the arctangent function) were plotted over time in this study. 


\subsection{Second flowering sequence}

The degree of $2^{\text {nd }} \mathrm{R}$ female flowers was evaluated by the following formula:

$$
2^{\mathrm{nd}} \mathrm{R}_{\varphi}=\left(\frac{N_{2^{\mathrm{nd}} F}}{N_{1^{\mathrm{st}} F}}\right) \times 100 \%
$$

where $N_{1^{\text {st }} F}$ and $N_{2^{\text {nd }} F}$ are the total number of the $1^{\text {st }} \mathrm{R}$ and $2^{\text {nd }} \mathrm{R}$ female flowers in 12 labeled panicles, respectively.

The relationships between $N_{1^{\mathrm{st} F}}$ and $N_{2^{\text {nd }} F}$, as well as the $2^{\text {nd }} R_{o}$ and FRR per week, in 2013 to 2014 were compared. At harvest, fruits produced by the $1^{\text {st }} \mathrm{R}$ flowers were separated from those developed by the $2^{\text {nd }} \mathrm{R}$ flowers, which were tagged with clips during fruit set. The fresh weight of seeds was measured in the $1^{\text {st }} \mathrm{R}$ fruits in both years and in the $2^{\text {nd }} \mathrm{R}$ fruits in 2014.

\subsection{Data collection and analysis}

Climate data including temperature, relative humidity and precipitation were recorded in Chiayi Agricultural Experiment Branch from November to April in both 2012/2013 and 2013/2014. The sunshine duration data in Chiayi City during the periods was extracted from the official website of the Central Weather Bureau (http://www.cwb.gov.tw). The numbers of days with a mean temperature below $20{ }^{\circ} \mathrm{C}$, below $15{ }^{\circ} \mathrm{C}$, and with daily precipitation of more than $0.1 \mathrm{~mm}$ during November-April in 2012/13 and 2013/14 were recorded, respectively. Regression analysis $(\alpha=0.05)$ and all the charts in the study were plotted with Microsoft Excel 2013 (Microsoft, USA).

\section{Results and discussion}

\subsection{Growth and maturation of 'Early Big' litchi fruit}

'Early Big' litchi fruit showed a sigmoid growth pattern based on fresh and dry weight (figure 1). Development of seed started about week 5 AFFB when the embryo was visible (figure 2). During week 7 AFFB, the liquid endosperm was exhausted, and the seed coat turned brown in the following week (figure 2). The aril started to grow rapidly at the same time (figure 1). The increase in seed dry mass slowed in week 9 AFFB (figure 1). The fruit pericarp turned yellowred at the same time, and became red in week 12 AFFB (figure 2). The single fruit weight and aril weight of 'Early Big' reached $36.5 \mathrm{~g}$ and $26.1 \mathrm{~g}$, respectively, on average in week 12 AFFB (figure 1). Titratable acidity decreased as the fruit developed, whereas the TSS contents increased up to $16^{\circ}$ Brix in week 10 AFFB (figure 3).

Maturity of litchi fruit can be evaluated by parameters such as the color of the pericarp, single fruit weight, edible ratio, titratable acidity content, and sugar/acid ratio (represented as TSS/TA) [20-22]. 'Early Big' fruit at 12 weeks AFFB seemed to have the most desirable qualities, including the conspicuous fruit size, $36.5 \mathrm{~g}$ per fruit on average, and red peel ( $f$ igures 1,2$)$. When fruit attained the equal edible ratio at $70 \%$ in
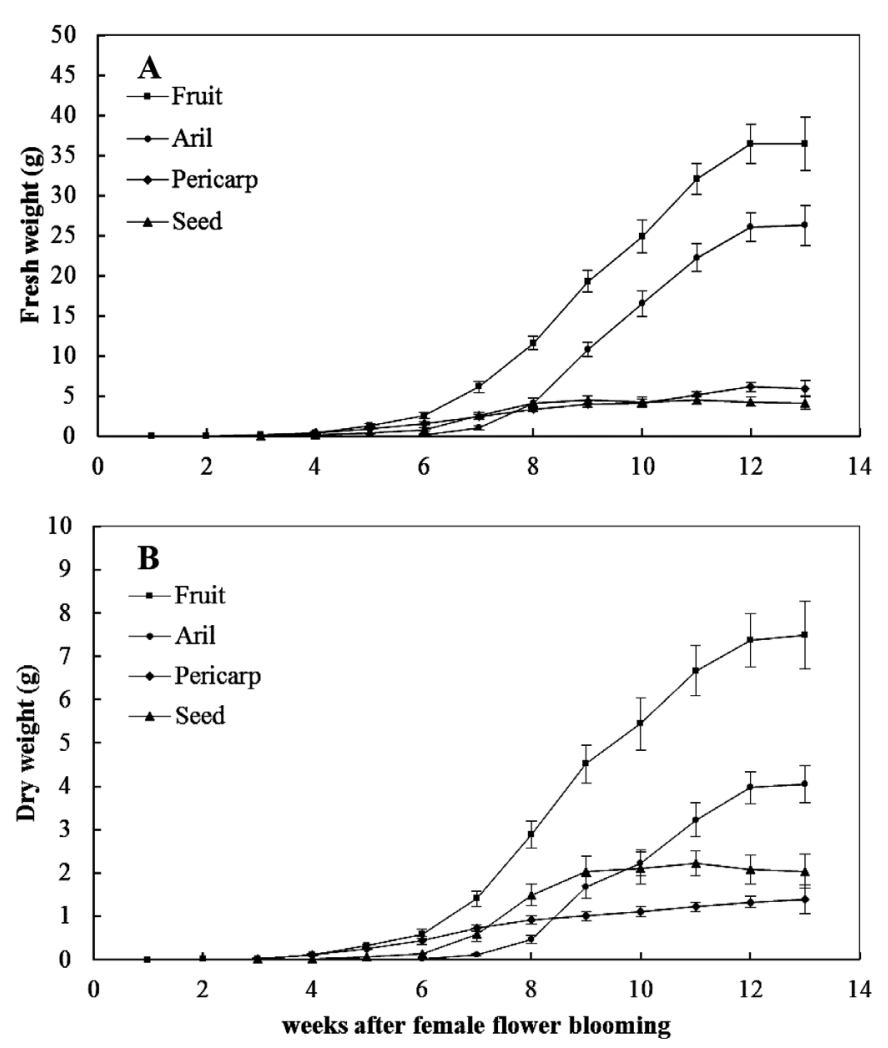

Figure 1. Cumulative growth of fruit, aril, pericarp, and seed in (A): fresh weight, and (B): dry weight, in 'Early Big' litchi in 2013. Data are mean values \pm standard deviation $(n=21)$.

'Early Big' (at 11 weeks AFFB) like its maternal parent 'Sah Keng' [23], the TSS/TA ratio in the juice of 'Early Big' fruit had already reached 28 (figure 3), which meets the requirement for trade, as suggested by Underhill and Wong [21] (figure 3). For other litchi cultivars, such as 'Brewster' [24], 'Hong Huey' and 'Chacapat' [25], different values of the sugar/acid ratio in juice, ranging from 15 to 30 , were recommended for fruit maturity evaluation due to different analysis methods used in the studies [25]. Early-season cultivars generally bloom earlier [26]. At least 11 weeks are required for fruit to develop to achieve commercial value in 'Early Big', 'Yu Her Pau' [27], and 'Hak Ip' [28]. This indicates that the trait of early maturing in 'Early Big' litchi compared with other major cultivars in Taiwan is mainly due to early flowering.

\subsection{Female blooming and fruit abscission patterns}

The $2^{\text {nd }} \mathrm{R}$ female flowering occurred $2-3$ weeks after the $1^{\text {st }} \mathrm{R}$ female blooming (figure 4). There was no obvious relationship between the amounts of the $1^{\text {st }} \mathrm{R}$ and the $2^{\text {nd }} \mathrm{R}$ female flowers in both years (figure 5). Unsynchronized maturation of fruits, produced respectively by the $1^{\text {st }} \mathrm{R}$ and $2^{\text {nd }} \mathrm{R}$ female flowers, may result in various fruit sizes among the fruits. A high seed abortion rate (23.6 to $38.6 \%$ ) was observed in the $1^{\text {st }} \mathrm{R}$ fruit with the middle $50 \%$ fresh weight $(\mathrm{FW})$ of seeds ranging from 1.9-4.6 $\mathrm{g}$ and $0.7-3.2 \mathrm{~g}$ in 2013 and 2014, respectively (figure 6). About $12.6 \%$ seeds in the $2^{\text {nd }} \mathrm{R}$ fruits in 2014 were 


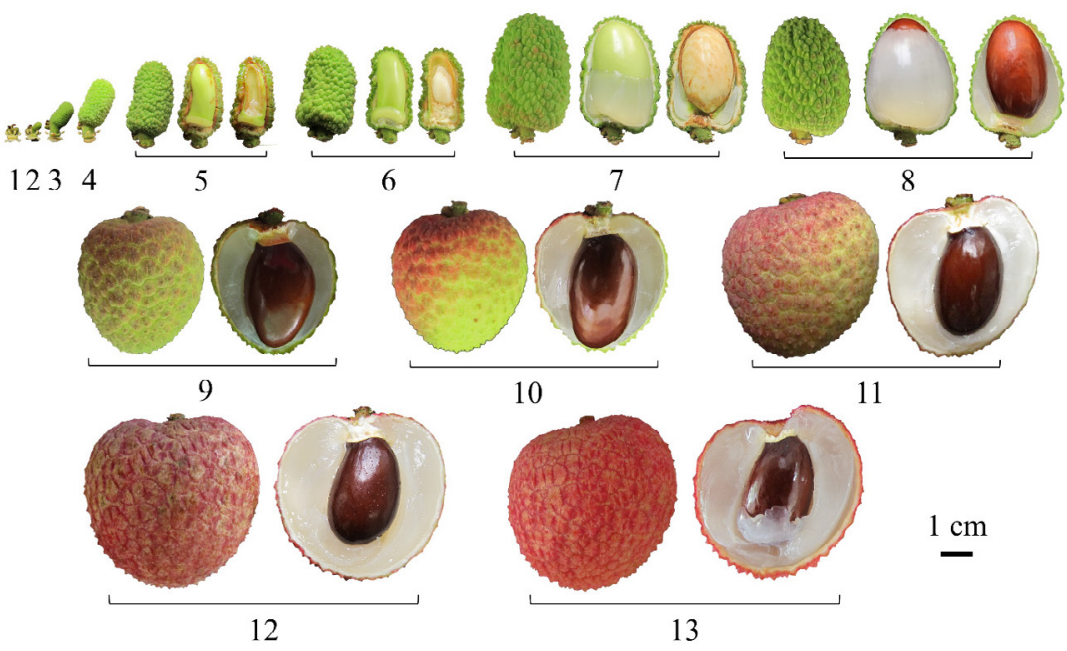

Figure 2. Fruit development of 'Early Big' litchi. Number under the fruit represents the number of weeks after female flowering. Bar $=1 \mathrm{~cm}$.

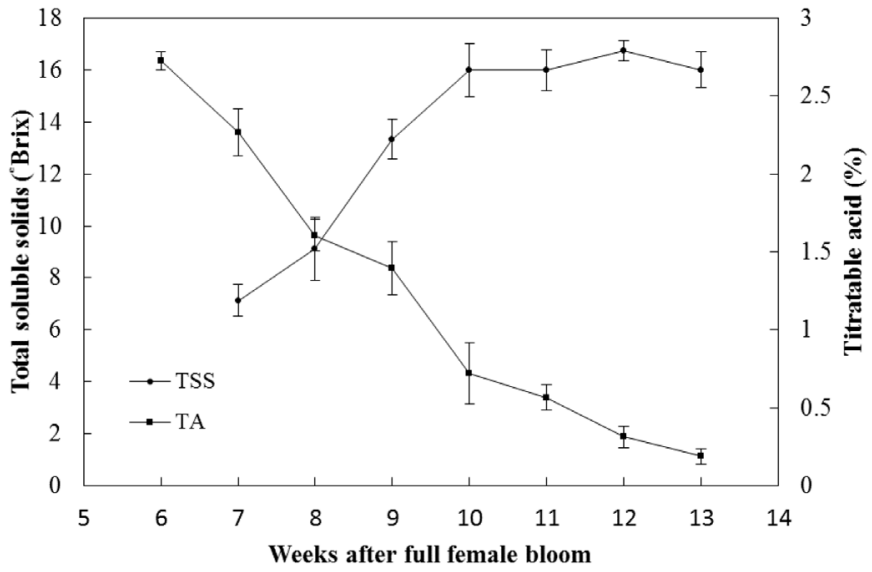

Figure 3. Changes in total soluble solid contents (TSS) and in titratable acidity (TA, represented by malic acid) of the juice during aril development in 'Early Big' litchi. Data are mean values \pm s.d. $(n=12$ and $n=4$ for TSS and TA, respectively).

shriveled, and the middle $50 \%$ mass varied from $1.8 \mathrm{~g}$ to $3.1 \mathrm{~g}$ FW (figure 6).

There were two rFAR waves during the first round of 'Early Big' fruit development (figure 7). The first wave of fruit abscission occurred within week 5 AFFB, in which more than $95 \%$ of fruit were lost. A sharp decrease in fruit numbers was observed in the first month AFFB, especially in 2014 (figure 7). The second wave of fruit abscission occurred between week 6 and week 8 AFFB, with the loss of 15 to $20 \%$ fruit. When the fruit reached commercial maturity in week 11 AFFB, 3\% fruit were harvested in 2013 , yet only $0.4 \%$ in 2014. Higher yield was also recorded in $2013\left(23.4 \mathrm{~kg}_{\text {tree }}{ }^{-1}\right)$ compared with $2014\left(10.8 \mathrm{~kg}\right.$ tre $\left.^{-1}\right)$. Although there was no obvious relationship between the second round female ratio $\left(2^{\text {nd }} \mathrm{R}_{Q}\right)$ and fruit retention rate (FRR) in 2014, the FRR was negatively correlated with the $2^{\text {nd }} \mathrm{R}_{\varphi}$ from week 4 AFFB in 2013 (figure 8).
Assimilate supply and carbon reserve availability are important to litchi fruit set [14,29]. Yuan et al. [30] revealed that early fruit retention within 3 weeks after blooming was positively correlated with starch content in small shoots with diameter of $2 \mathrm{~cm}$ in 'Nuomici' litchi. In the case of 'Yu Her Pau' production in Taiwan, inflorescence thinning at the beginning of anthesis effectively improves yield [31], suggesting an inverse relationship between the numbers of flowers and fruits due to competition for limited resources. This might be the scenario underlying our observation in 'Early Big' that the $2^{\text {nd }} R_{\rho}$ was negatively correlated with the retention rate of the $1^{\text {st }} \mathrm{R}$ fruit after week 4 AFFB in 2013 (figure 8 ), since the $2^{\text {nd }} R$ female flowers and subsequent $2{ }^{\text {nd }} \mathrm{R}$ fruit were produced in the presence of the $1^{\text {st }} \mathrm{R}$ fruit on the same pedicles. However, the correlation did not exist in 2014 that massive fruit drop happened. In addition, based on the results of the regression analysis, the number of the $2^{\text {nd }} \mathrm{R}$ female flowers was independent of the number of $1^{\text {st }} \mathrm{R}$ female flowers and initial fruit set in 'Early Big' (figure 5, figure 8). Although the presence of the $2^{\text {nd }} \mathrm{R}$ female seems to be genetically inherited, the mechanism is not fully understood $[32,33]$. To some degree, $2^{\text {nd }} \mathrm{R}$ female flowering may be linked to certain internal and/or external conditions. When maturation of vegetative flushes was delayed, a high number of $2^{\text {nd }} \mathrm{R}$ flowers was produced in 'Rose Red' litchi [8].

\subsection{Influence of climatic factors on fruit abscission}

Since environmental factors may play a role in regulating floral development in litchi, the climate information including ambient temperature, sunshine duration, relative humidity and precipitation during the trials was recorded (table I). Overall, the duration of low temperature was longer and cooler in 2013/2014 compared with the first year, especially during February-March. The mean daily temperature from November to March dropped below $20{ }^{\circ} \mathrm{C}$ for 83 days in $2012 / 2013$ versus 106 days in $2013 / 2014$, and below $15^{\circ} \mathrm{C}$ for 10 days 

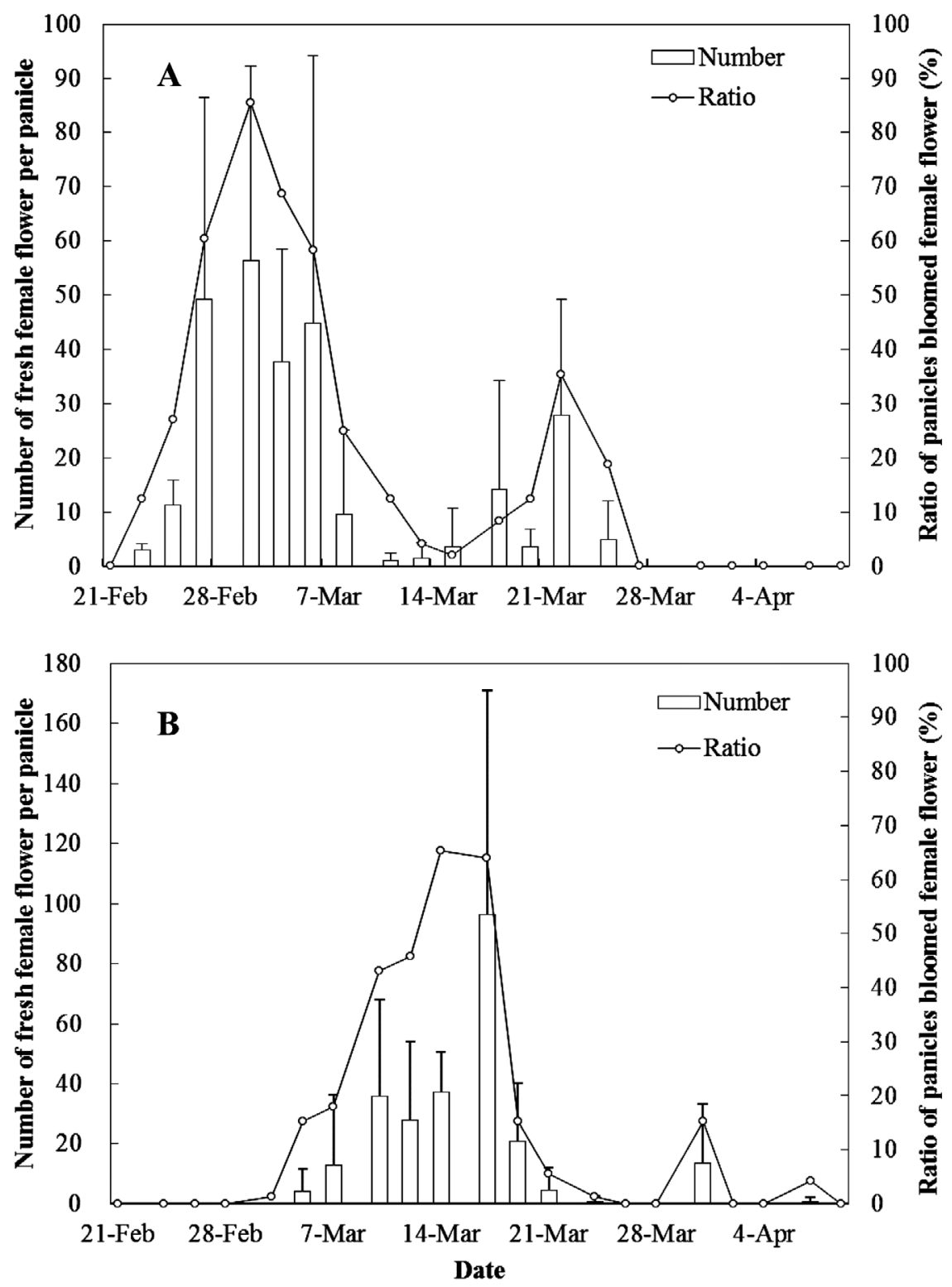

Figure 4. Patterns of female blooming in 'Early Big' litchi in (A): 2013 and (B): 2014. Vertical bars indicate the number of female flowers per panicle \pm s.d. ( $n=48$ and $n=72$ in 2013 and 2014, respectively). The ratio of bloomed female flowers per panicle along the period is represented in broken lines.

in 2012/2013 versus 29 days in 2013/2014 (table I). Sunshine duration in January and April 2014 was greater compared with the previous crop year. Lower sun exposure with higher relative humidity was recorded in February-March 2014 compared with 2013. In 2014, there was frequent precipitation in February, while the precipitation was similar in the blooming season in both years.

Full female blooming in 'Early Big' was delayed in 2014 for 2 weeks, compared with the previous year (figure 4), along with poor fruit retention due to fruit drop (figure 7). Late flowering can be explained as the result of low temperature. Although a cool environment is required for litchi flowering $[6,7]$, panicle emergence and anthesis can be delayed in trees grown under low temperature conditions [34-36]. There were two waves of fruit abscission within two months following full female bloom (figure 7). In fact, massive fruit drop is common in litchi cultivars. 'Mauritius', that shares a similarity in the pattern of fruit abscission with 'Early Big', suffered the loss of 90 to $95 \%$ fruit in the first month AFFB [37]. A high rate of fruit abscission was also reported in 'Yu Her Pau', 'Floridian' and 'Kaimana' at this stage [27, 32,38]. Our data indicated that the level of fruit drop during the first month AFFB critically contributes to the loss in total yield of 'Early Big' litchi.

It has been proposed that failure in pollination and/or fertilization causes the first wave of fruit abscission [32,33]. Environmental factors, such as low temperature, low humidity and rain may enhance fruit drop [39]. These external factors 
Table I. Monthly climatic information at Chiayi Agricultural Experiment Branch from November to April in 2012/13 and 2013/14.

\begin{tabular}{|c|c|c|c|c|c|c|c|c|c|c|}
\hline \multirow[b]{3}{*}{ Month } & \multicolumn{6}{|c|}{ Temperature $\left({ }^{\circ} \mathrm{C}\right)$} & \multicolumn{4}{|c|}{ Cool days } \\
\hline & \multicolumn{2}{|c|}{ Minimum (date) } & \multicolumn{2}{|c|}{ Maximum (date) } & \multicolumn{2}{|c|}{ Mean } & \multicolumn{2}{|c|}{$\begin{array}{c}\text { Number of daily } \\
\text { temperature }<20^{\circ} \mathrm{C}\end{array}$} & \multicolumn{2}{|c|}{$\begin{array}{c}\text { Number of daily } \\
\text { temperature }<15^{\circ} \mathrm{C}\end{array}$} \\
\hline & $2012 / 13$ & $2013 / 14$ & $2012 / 13$ & $2013 / 14$ & $2012 / 13$ & $2013 / 14$ & $2012 / 13$ & $2013 / 14$ & $2012 / 13$ & $2013 / 14$ \\
\hline November & $14.2(27)$ & $8.5(30)$ & $32.2(10)$ & $30.7(1)$ & 21.9 & 21.4 & 3 & 9 & 0 & 2 \\
\hline December & $7.7(31)$ & $6.3(28)$ & $28.9(16)$ & $27.5(7)$ & 18.3 & 16.5 & 22 & 25 & 3 & 8 \\
\hline January & 8.5 (19) & $6.0(25)$ & $26.4(21)$ & $26.8(2)$ & 16.3 & 15.8 & 31 & 31 & 6 & 9 \\
\hline February & $12.4(1)$ & $5.3(21)$ & $28.8(18)$ & $28.5(5)$ & 19.1 & 16.7 & 19 & 22 & 0 & 9 \\
\hline March & $12.1(3)$ & $12.3(15)$ & $31.1(23)$ & $32.0(29)$ & 20.9 & 19.7 & 8 & 19 & 1 & 1 \\
\hline April & $14.7(7)$ & $16.1(5)$ & $31.5(30)$ & 30.9 (27) & 22.3 & 23.4 & 2 & 0 & 0 & 0 \\
\hline
\end{tabular}

\begin{tabular}{|c|c|c|c|c|c|c|c|c|}
\hline \multirow[b]{3}{*}{ Month } & \multirow{2}{*}{\multicolumn{2}{|c|}{$\begin{array}{c}\text { Sunshine duration* }(\mathrm{h}) \\
\text { Monthly total }\end{array}$}} & \multirow{2}{*}{\multicolumn{2}{|c|}{$\begin{array}{c}\text { Relative humidity (\%) } \\
\text { Mean }\end{array}$}} & \multicolumn{4}{|c|}{ Precipitation $(\mathrm{mm})$} \\
\hline & & & & & \multicolumn{2}{|c|}{ Monthly total } & \multicolumn{2}{|c|}{$\begin{array}{c}\text { Number of daily } \\
\text { precipitation }>0.1 \mathrm{~mm}\end{array}$} \\
\hline & $2012 / 13$ & $2013 / 14$ & $2012 / 13$ & $2013 / 14$ & $2012 / 13$ & $2013 / 14$ & $2012 / 13$ & $2013 / 14$ \\
\hline November & 124.5 & 116.4 & 69 & 70 & 94.0 & 10.0 & 10 & 2 \\
\hline December & 121.1 & 139.3 & 69 & 70 & 38.0 & 48.0 & 6 & 6 \\
\hline January & 155.1 & 236.7 & 68 & 64 & 14.5 & 0 & 4 & 0 \\
\hline February & 157.9 & 136.5 & 67 & 73 & 5.0 & 34.0 & 2 & 11 \\
\hline March & 181.3 & 131.0 & 64 & 70 & 38.0 & 47.5 & 5 & 5 \\
\hline April & 89.9 & 138.4 & 72 & 71 & 142.5 & 19.5 & 15 & 7 \\
\hline
\end{tabular}

*Sunshine duration data were extracted from the official website of Central Weather Bureau (http://www.cwb.gov.tw).
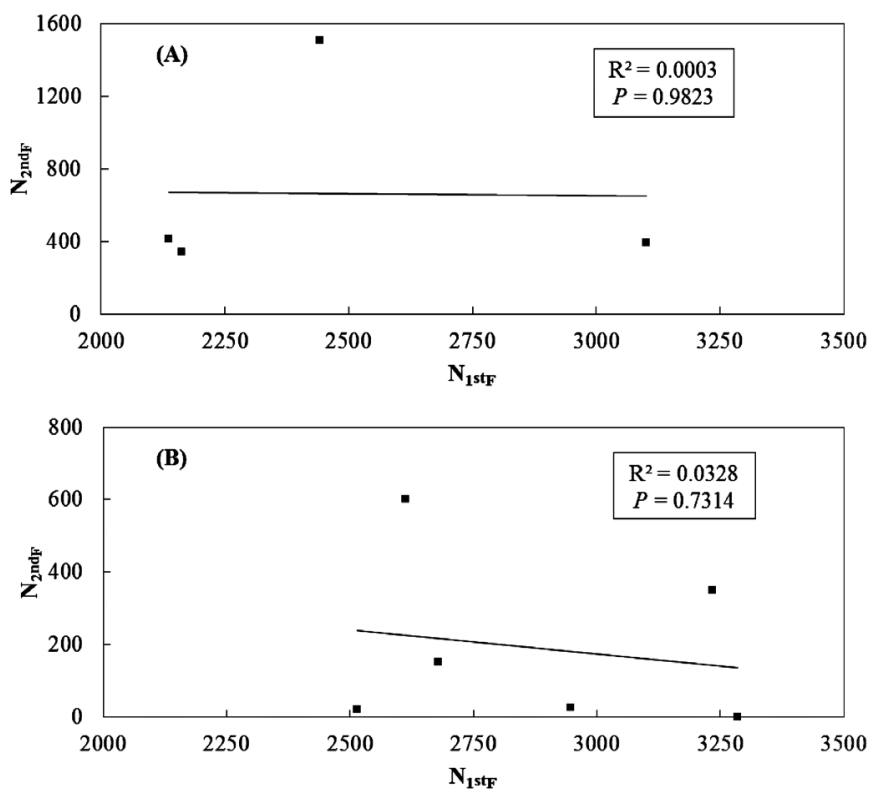

Figure 5. Correlation between the total number of the $1^{\text {st }} \mathrm{R}$ and $2^{\text {nd }} \mathrm{R}$ female flowers in labeled panicles (represented by $\mathrm{N}_{1^{\mathrm{st}} \mathrm{F}}$ and $\mathrm{N}_{2^{\text {nd }} \mathrm{F}}$, respectively) in (A): 2013, and (B): $2014(n=12)$.

act directly on the plant itself or indirectly through the pollination process. For example, the temperature in the blooming season remarkably affects embryo sac development and pollen germination, thereby influencing litchi fruit set $[10,11]$. Extreme environmental conditions such as adverse temperature,

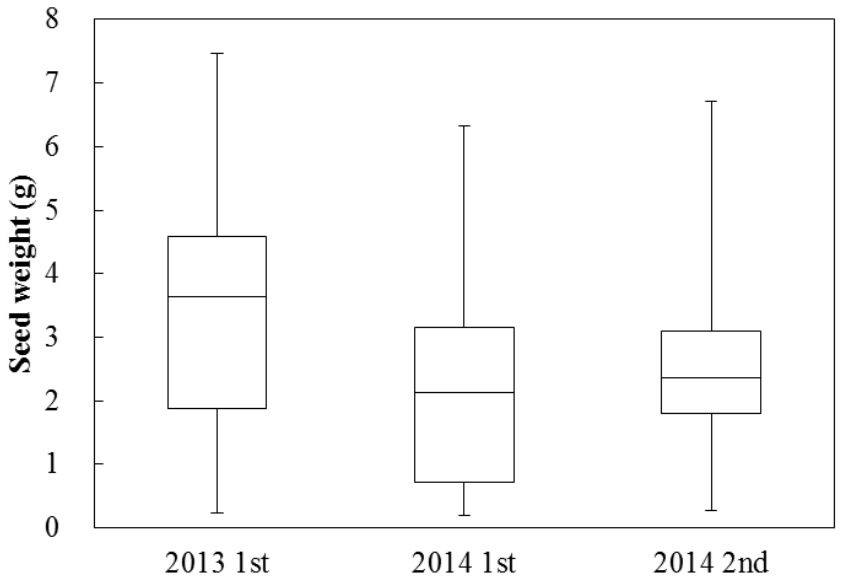

Figure 6. Box plot of fresh seed weight of 'Early Big' litchi in the $1^{\text {st }} \mathrm{R}$ fruit in 2013, the $1^{\text {st }} \mathrm{R}$ fruit in 2014 , and the $2^{\text {nd }} \mathrm{R}$ fruit in 2014. Boxes represent $25 \%$ to $75 \%$ quartiles with the median (horizontal lines), and the whiskers ended in the extreme values ( $n=148,70$ and 175 in the respective order).

cloud cover, precipitation and wind reduce the forage activity of pollinators and thereby result in decrease in yield in litchi production [40]. In our study, a smaller seed size and higher seed abortion rate in the $1^{\text {st }} \mathrm{R}$ fruit was observed in 2014, compared with those produced in the $1^{\text {st }} \mathrm{R}, 2013$ and the $2^{\text {nd }} R, 2014$ (figure 6). Shorter sunshine duration in the blooming season in 2014 may have diminished pollinator foraging, whereas temperature is usually the key factor influencing litchi fruit set. In Queensland, Australia, the rate of fruit set from 


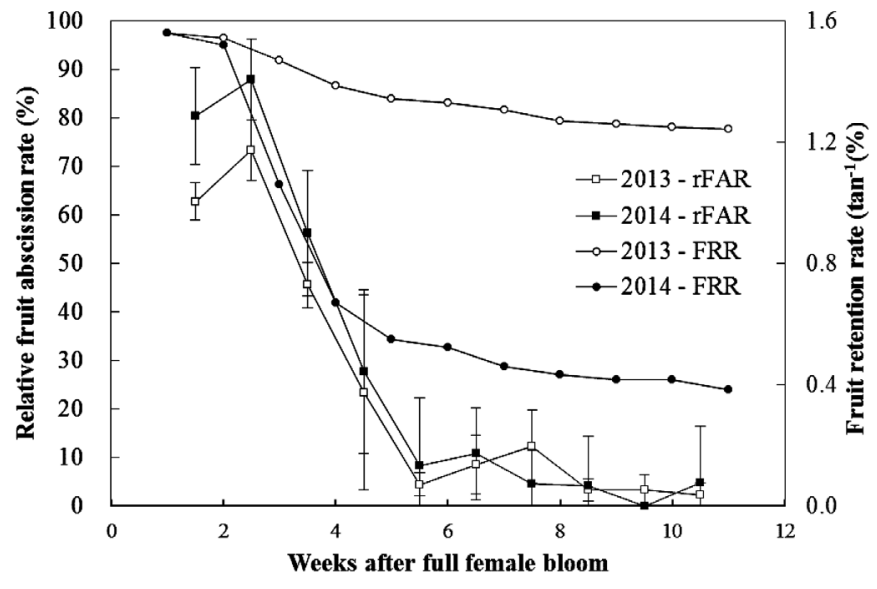

Figure 7. Patterns of the relative fruit abscission rate (rFAR, squares) and of the fruit retention rate (FRR, circles) in 'Early Big' litchi in 2013 (open symbols, $n=4$ ) and 2014 (closed symbols, $n=6$ ). rFAR data are mean values \pm s.d., FRR data (adjusted by arctangent transformation) are expressed by mean values.
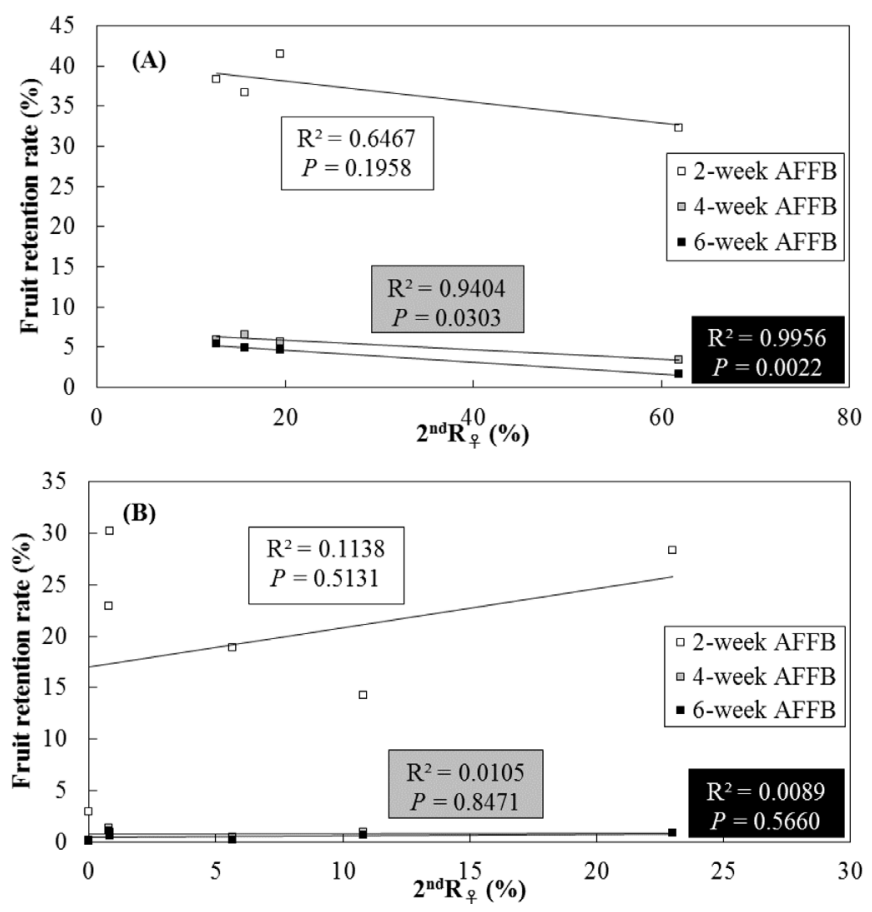

Figure 8. Correlation between the second round female ratio $\left(2^{\text {nd }} R_{\varphi}\right)$ and the fruit retention rate (relative to the fruit number in the first week AFFB) after week-2, week-4, and week-6 after full female bloom (AFFB) in (A): 2013, and (B) 2014. $\mathrm{R}^{2}$ and $\mathrm{P}$ values in the regression analyses for each week per year were labeled in the block with the respective colored symbols.

female flowers was increased by a higher maximum temperature during anthesis [41]. Chen et al. [31] showed that a cool temperature just before flowering would negatively influence the following fruit set of 'Yu Her Pau' litchi. Poor pollination and/or fertilization in the $1^{\text {st }} \mathrm{R}$ flowers in 'Early Big' were possibly related to the cool temperature in the early spring of 2014 (table I). Other climate factors including relative humidity and precipitation were similar in the $1^{\text {st }} \mathrm{R}$ blooming seasons of 2013 and 2014, suggesting that these two factors may not have played a crucial role in inhibiting pollination and/or fertilization in 2014.

\section{Conclusion}

Early blooming is an essential trait that makes the earlymaturing litchi cultivars such as 'Early Big' more profitable. However, low ambient temperature before and/or during anthesis may potentially negatively influence flowering in these early-blooming litchi cultivars. Ambient temperature is one of the factors regulating the flowering time and the subsequent fruit set. It is still unclear how a cool temperature just before and/or during the blooming season affects early flowering and fruit set in litchi. However, our study of the generative performance in 'Early Big' showed that accumulation of low temperatures in early spring may be related to poor initial fruit set. Our results also indicated that young developing $1^{\text {st }} \mathrm{R}$ fruits may be inhibited by the presence of $2^{\text {nd }} \mathrm{R}$ female flowers produced within 2 to 3 weeks after the $1^{\text {st }} R$, at which $1^{\text {st }} R$ fruits were still on the trees. The $2^{\text {nd }} \mathrm{R}$ litchi fruits have poor commercial value, especially for 'Early Big', because its fruits are harvested during the peak season of the litchi market. Therefore, horticultural practices need to be developed in the future, in order to mitigate the problems of poor fruit set of $1^{\text {st }} \mathrm{R}$ fruits and $2{ }^{\text {nd }} \mathrm{R}$ flowering in 'Early Big' litchi trees.

Acknowledgements. The authors gratefully acknowledge the support from the Council of Agriculture of the Republic of China, Taiwan (project no. 103AS-9.2.3-CI-C4), and the assistance with field management of Mr. Mau-Nan Liu.

\section{References}

[1] Chang J.W., Teng Y.S., Yen C.R., Description and performance of new litchi varieties, in: Fang H.H., Teng Y.S., Lee W.L. (Eds.), Proceedings of the Symposium on Litchi Industry Development in Taiwan, Taichung, Taiwan, 2012, pp. 25-37.

[2] Groff G.W., Some ecological factors involved in successful lychee culture, Proc. Fla. State Hort. Soc. 56 (1943) 134-155.

[3] Yuan R., Huang H., Litchi fruit abscission: its patterns, effect of shading and relation to endogenous abscisic acid, Scientia Hort. 36 (1988) 281-292.

[4] McConchie C.A., Batten D.J., Fruit set in lychee (Litchi chinensis Sonn.). Variation between flowers, panicles and trees, Aust. J. Agric. Res. 42 (1991) 1163-1172.

[5] Batten D.J., Lahav E., Base temperature for growth processes of lychee, a recurrently flushing tree, are similar but optima differ, Aust. J. Plant Physiol. 21 (1994) 589-602.

[6] Menzel C.M., Simpson D.R., Temperature above $20{ }^{\circ} \mathrm{C}$ reduce flowering in lychee (Litchi chinensis Sonn.), J. Hort. Sci. 70 (1995) 981-987. 
[7] O'Hare T.J., Interaction of temperature and vegetative flush maturity influences shoot structure and development of lychee (Litchi chinensis Sonn.), Scientia Hort. 95 (2002) 203-211.

[8] Chang J., Chang Y.A., Fang M.Y., Lin M.L., Chang J.W., Estimation of the putative marginal timing for subsequent flowering in the last flush of litchi, J. Taiwan Soc. Hort. Sci. 60 (2014) 27-39.

[9] Stern R.A., Gazit S., Lychee pollination by the honeybee, J. Amer. Sco. Hort. Sci. 120 (1996) 152-157.

[10] Stern R.A., Eisenstein D., Voet H., Gazit S., Anatomical structure of two day old litchi ovules in relation to fruit set and yield, J. Hort. Sci. 71 (1996) 661-671.

[11] Stern R.A., Gazit S., Pollen viability in lychee, J. Am. Sco. Hort. Sci. 123 (1998) 41-46.

[12] Hieke S., Menzel C.M., Doogan V.J., Lüdders P, The relationship between fruit and leaf growth in lychee (Litchi chinensis Sonn.), J. Hort. Sci. Biotech. 77 (2002) 320-325.

[13] Hieke S., Menzel C.M., Doogan V.J., Lüdders P, The relationship between yield and assimilate supply in lychee (Litchi chinensis Sonn.), J. Hort. Sci. Biotech. 77 (2002) 326-332.

[14] Chang J.C., Lin T.S. Fruit yield and quality as related to flushes of bearing shoots in litchi, J. Amer. Soc. Hort. Sci. 133 (2008) 284-289.

[15] Holcroft D.M., Mitcham. E.J., Postharvest physiology and handling of litchi (Litchi chinensis Sonn.), Postharvest Biol. Technol. 9 (1996) 265-281.

[16] Sarin N.B., Prasad U.S., Kumar M., Jain S.M., Litchi breeding for genetic improvement, in: Jain S.M., Priyadarshan P.M. (Eds.), Breeding plantation tree crops: Tropical species, Springer, Heidelberg, Germany, 2009, pp. 217-245.

[17] Yen C.R., Laio Y.W., Tien Y.J., The cultivars of litchi (Litchi chinensis Sonn.) and their improvement in Taiwan, J. Chinese Soc. Hort. Sci., 30 (1984) 210-222.

[18] Chang J.W., Yen C.R., Wang W.L., Liu M.N., Chang J., Breeding of novel litchi cultivar 'Tainung No.7 (Early Big)', J. Taiwan Agric. Res. 63 (2014) 43-56.

[19] Wang H.C., Huang H.B., Huang X.M., Hu Z.Q., Sugar and acid compositions in the arils of Litchi chinensis Sonn.: cultivar differences and evidence for the absence of succinic acid, J. Hort. Sci. Biotech. 81 (2006) 57-62.

[20] Batten D.J., Maturity criteria for litchis (lychees), Food Qual. and Prefer. 1 (1989) 149-155.

[21] Underhill S.J.R., Wong L.S., A maturity standard for lychee (Litchi chinensis Sonn.), Acta Hort. 269 (1990) 181-187.

[22] Cao Y., Jiang Y., Gao H., Chen H., Fang X., Mua H., Tao F., Development of a model for quality evaluation of litchi fruit, Comput. Electron. Agric. 106 (2014) 49-55.

[23] Yen C.R., Seeded and seedless fruits growth of 'Sah Keng' litchi, J. Agric. Res. China 33 (1984) 257-264.

[24] Finger F.L., Vieira G., Ledsham. L.R., Maturity standard and pericarp browning of litchi fruit, R. Bras. Fisiol. Veg. 9 (1997) $15-18$.
[25] Reichel M., Carle R., Sruamsiri, P., Neidhart S., Influence of harvest maturity on quality and shelf-life of litchi fruit (Litchi chinensis Sonn.), Postharvest Biol. Technol. 57 (2010) 162175.

[26] Huang H., Xu. J. The development patterns of fruit tissues and their correlative relationships in Litchi chinensis Sonn., Scientia Hort. 19 (1983) 335-342.

[27] Chang J.C., Studies on Fruit Set in 'Yu Her Pau' and 'No Mai Tsz (73-S-20)' Litchi (Litchi chinensis Sonn.), National Taiwan University, Taipei, Taiwan, Ph.D. Dissertation, 2004, 318 p.

[28] Yeh Y.C., Chang J.W., Tang C.H., Lin F.T., Lee T.C., Study on the development of 'Tainung No.1' and 'Hak Ip' litchi (Litchi chinensis Sonn.) fruits, J. Taiwan Soc. Hort. Sci. 57 (2011) 65-79.

[29] Roe D.J., Menzel C.M., Oosthuizen J.H., Doogan V.J., Effects of current $\mathrm{CO}_{2}$ assimilation and stored reserves on lychee fruit growth, J. Hort. Sci. 72 (1997) 397-405.

[30] Yuan W.Q., Huang X.M., Wang H.C., Li J.G., Chen H.B., Yin J.H., Seasonal changes in carbon nutrition reserve in Nuomici litchi trees and its relation to fruit load, Acta Hort. Sinica 36 (2009) 1568-1574.

[31] Chen P.A., Roan S.F., Lee C.L., Chen I.Z., The effect of temperature during inflorescence development to flowering and inflorescence length on yield of 'Yu Her Pau' litchi, Scientia Hort. 159 (2013) 186-189.

[32] Stern R.A., Gazit S., The reproductive biology of the lychee, Hort. Rev. 28 (2003) 393-453.

[33] Mustard M.J., Liu S.Y., Lynch. S.J., Observations of floral biology and fruit-setting in lychee varieties, Proc. Fla. State Hort. Soc. 66 (1953) 212-220.

[34] Menzel C.M., Simpson. D.S., Effects of temperature on growth and flowering of litchi (Litchi chinensis Sonn.) cultivars, J. Hort. Sci. 63 (1988) 349-360.

[35] Menzel C.M., Simpson. D.S., Growth, flowering and yield of lychee cultivars, Scientia Hort. 49 (1992) 243-254.

[36] O'Hare T.J., Impact of root and shoot temperature on bud dormancy and floral induction in lychee (Litchi chinensis Sonn.), Scientia Hort. 99 (2004) 21-28.

[37] Stern R.A., Kigel J., Tomer E., Gazit S., 'Mauritius' lychee fruit development and reduced abscission after treatment with the auxin 2,4,5-TP, J. Am. Soc. Hort. Sci. 120 (1995) 65-70.

[38] Stern R.A., Gazit S., The synthetic auxin 3,5,6-TPA reduces fruit drop and increases yield in 'Kaimana' litchi, J. Hort. Sci. Biotech. 74 (1999) 203-205.

[39] Batten D.J., Towards an understanding of reproductive failure in lychee (Litchi chinensis Sonn.), Acta Hort. 175 (1986) 79-83.

[40] Menzel C.M., The pattern and control of reproductive development in lychee: a review, Scientia Hort. 22 (1984) 333-345.

[41] Menzel C.M., Simpson. D.S., Flowering and fruit set in lychee (Litchi chinensis Sonn.) in subtropical Queensland, Aust. J. Exp. Agr. 32 (1992) 105-111. 